\title{
ANALISIS SALURAN PEMASARAN AYAM BURAS DI KABUPATEN BANYUWANGI
}

\author{
Marketing Channel Analysis of Local Chicken in Banyuwangi Regency
}

\author{
Anang Febri Pasetyo dan Bayu Aminulloh Fatah \\ Jurusan Peternakan, Politeknik Negeri Jember \\ Email: anangfebri@polije.ac.id
}

\begin{abstract}
INTISARI
Penelitian ini bertujuan untuk mengetahui bentuk-bentuk pemasaran ayam buras, margin pemasaran, keuntungan dan tingkat efisiensi pada masing-masing saluran pemasaran ayam buras yang ada di Kabupaten Banyuwangi. Jumlah responden yaitu sebesar 195 yang terdiri dari peternak, pengepul, pedagang besar, rumah potong ayam (RPA), pengecer, dan konsumen. Metode yang digunakan yaitu metode analisis deskriptif. Hasil penelitian menunjukkan bahwa terdapat 4 bentuk saluran pemasaran ayam buras di Kabupaten Banyuwangi yaitu saluran 1 (peternak ke konsumen), saluran 2 (peternak ke pengepul dan konsumen), saluran 3 (peternak ke pengepul ke pedagang besar dan konsumen), saluran 4 (peternak ke pengepul ke pedagang besar ke RPA ke pengecer ke konsumen). Total margin pemasaran paling besar terdapat pada saluran 4 yaitu sebesar Rp51.000,00 dan paling kecil terdapat pada saluran 1 sebesar Rp0,00. Jumlah keuntungan terbanyak pada pemasaran ayam buras di Kabupaten Banyuwangi yaitu pada RPA saluran 4 sebesar Rp15.433,33/ekor dan keuntungan terkecil pada pedagang pengepul saluran 2 sebesar Rp5.893,37/ekor. Persentase keuntungan terbesar dari pemasaran ayam buras yang ada di Kabupaten Banyuwangi yaitu pada RPA saluran 4 sebesar 31\%, dan persentase keuntungan terkecil terdapat pada peternak saluran 1 sebesar $5 \%$. Tingkat efisiensi pemasaran ayam buras di Kabupaten Banyuwangi berdasarkan biaya pemasaran dan saluran pemasaran dinyatakan efisien.
\end{abstract}

Kata Kunci: Saluran Pemasaran, Margin, Keuntungan, Efisiensi Pemasaran

\begin{abstract}
This study aimed to evaluate the marketing channel of domestic chicken, marketing margins, profit and efficiency level in Banyuwangi Regency. The respondents were 195 consisting of farmers, collectors, wholesalers, chicken slaughterhouses, retailers, and consumers. The method usage was descriptive analysis. The results showed that there were 4 patterns of marketing channels for domestic chicken in Banyuwangi Regency, namely channel 1 (farmers to consumers), channel 2 (farmers to collectors and consumers), channel 3 (breeders to collectors to wholesalers and consumers), channel 4 (breeders to collectors to wholesalers to chicken slaughterhouses to retailers to consumers). The biggest total marketing margin on channel 4 was IDR 51,000.00 and the smallest on channel 1 was IDR 0,00. The highest profit on domestic chicken marketing in Banyuwangi Regency was on channel 4 (chicken slaughterhouses) as much as IDR 15,433.33/head and the lowest profit on channel 2 (traders) as much as IDR 5,893.37/head. The highest percentage of profit on channel 4 (chicken slaughterhouses) as much as 31\%, and the lowest percentage of profit on channel 1 (farmers) as much as 5\%. The efficiency of domestic chicken marketing in Banyuwangi Regency based on marketing costs and marketing channels were declared efficient.
\end{abstract}

Keywords: Marketing Channels, Margin, Profit, Marketing Efficiency

\section{PENDAHULUAN}

Ayam buras merupakan ayam lokal asli Indonesia yang cukup berpotensi untuk dikembangkan. Data statistik Kabupaten
Banyuwangi pada tahun 2013 jumlah ayam buras sebanyak 1.290 .339 ekor, tahun 2014 sebanyak 1.247 .721 ekor, dan tahun 2015 sebanyak 1.152.352 ekor (BPS Kabupaten Banyuwangi, 2015). Ayam buras harus dijaga 
kelestariannya guna menjaga kemurnian dari ayam khas Indonesia, selain itu potensi ayam buras juga perlu dikembangkan untuk kebutuhan pangan masyarakat. Ayam buras memiliki keungulan dibandingkan dengan ternak unggas yang lain seperti ayam ras pedaging (broiler) yaitu daya tahan terhadap serangan penyakit yang kuat, cepat beradaptasi dengan lingkungan, tidak mudah stres, dan dagingnya lebih disukai oleh masyarakat (Rasyaf, 2011).

Ayam buras yang ada di masyarakat dipelihara dengan cara diumbar, pemberian pakan seadanya, dan tindak lanjut dari pemasaran ayam buras belum banyak diketahui oleh masyarakat luas. Permasalahan pemasaran ayam buras yaitu ketersediaannya yang semakin sedikit. Penurunan populasi selama 3 tahun terakhir menjadikan kebutuhan permintaan ayam buras semakin meningkat. Hal tersebut menyebabkan harga ayam buras menjadi lebih tinggi (mahal) dibanding harga ayam broiler. Jalur distribusi pemasaran ayam buras dari produsen sampai kepada konsumen masih belum banyak diketahui oleh masyarakat dan tingginya margin pemasaran pada setiap pihak yang terkait dalam pemasaran ayam buras menyebabkan harga yang bervariasi di tingkat konsumen. Oleh karena itu, perlu dilakukan penelitian mengenai saluran pemasaran, margin pemasaran, keuntungan, dan efisiensi pemasaran ayam buras di Kabupaten Banyuwangi.

\section{MATERI DAN METODE}

Penentuan lokasi penelitian dilakukan dengan cara purposive yaitu di Kabupaten Banyuwangi. Populasi yang digunakan dalam penelitian ini adalah seluruh komponen yang terlibat dalam rantai pemasaran ayam buras di Kabupaten Banyuwangi yang terdiri dari peternak, pengepul, pedagang besar, rumah potong ayam (RPA), pedagang pengecer, dan konsumen. Parameter yang diamati yaitu saluran pemasaran, margin pemasaran, keuntungan, dan tingkat efisiensi pemasaran.

\section{Saluran Pemasaran}

Saluran pemasaran diperoleh dengan metode snowball sampling (Sugiyono, 2011), yaitu dengan mengikuti rantai pemasaran hingga sampai ke konsumen.

\begin{tabular}{l} 
Margin Pemasaran \\
Margin pemasaran akan di hitung \\
dengan rumus (Rais, 2013) \\
\hline $\mathrm{Mp}=\mathrm{Hk}-\mathrm{Hp}$ \\
\hline
\end{tabular}

Keterangan:

$\mathrm{Mp}=$ Margin pemasaran

$\mathrm{Hp}=$ Harga beli ayam

$\mathrm{Hk}$ = Harga jual ayam

\section{Keuntungan}

Keuntungan yang diperoleh masingmasing lembaga pemasaran ayam broiler, digunakan rumus (Thalib, 2013).

$$
\Pi=\mathrm{M}-\mathrm{Bp}
$$

Keterangan:

$\Pi=$ Keuntungan lembaga pemasaran

$\mathrm{Bp}=$ Biaya penjualan

$\mathrm{M}=$ Margin pemasaran

\section{Tingkat Efisiensi Pemasaran}

Perhitungan tingkat efisiensi pemasaran pada masing-masing saluran pemasaran di dalam penelitian ini menggunakan rumus menurut Rosmawati (2011).

$$
\text { Eps }=\frac{B}{H E} \times 100
$$

Keterangan:

Eps $=$ Efisiensi pemasaran

$\mathrm{B}=$ Biaya pemasaran

$\mathrm{HE}$ = Harga eceran

Dengan asumsi

$\begin{array}{ll}0-33 \% & =\text { Efisiensi Pemasaran } \\ 34-67 \% & =\text { Kurang Efisien } \\ 68-100 \% & =\text { Tidak Efisien }\end{array}$

\section{Analisis Data}

Analisis data menggunakan analisis deskriptif (Arikunto dan Suharsimi, 2010). Analisis deskriptif dimaksudkan untuk menguraikan secara kualitatif keadaan yang sebenarnya ada di lapangan tentang pemasaran ayam buras. Analisis biaya digunakan untuk mengetahui margin pemasaran, keuntungan, dan tingkat efisiensi pemasaran. 


\section{HASIL DAN PEMBAHASAN}

\section{Saluran Pemasaran}

Lembaga yang terlibat dalam pemasaran ayam buras di Kabupaten Banyuwangi yaitu peternak, pengepul, pedagang besar, RPA, pedagang pengecer, dan konsumen. Saluran pemasarannya terdapat 4 pola. Pola 1: peternak $\rightarrow$ konsumen; Pola 2: peternak $\rightarrow$ pengepul $\rightarrow$ konsumen. Pola 3 : peternak $\rightarrow$ pengepul $\rightarrow$ pedagang besar $\rightarrow$ konsumen. Pola 4: peternak $\rightarrow$ pengepul $\rightarrow$ pedagang besar $\rightarrow$ RPA $\rightarrow$ pedagang pengecer $\rightarrow$ konsumen.
Menurut pendapat Amalia et al. (2013) bahwa semakin banyak pedagang perantara yang terlibat dalam saluran pemasaran maka akan semakin tinggi pula harga yang harus dibayarkan oleh konsumen. Hasil penelitian Nazaruddin et al. (2011) menyebutkan bahwa pada saluran pemasaran adalah salah satu faktor penentu untuk meningkatkan hasil penjualan. Saluran pemasaran tersebut merupakan jalur penyampaian suatu produk, jika saluran tersebut dapat dimanfaatkan dengan baik dan optimal, maka konsumen dapat dengan mudah memperoleh produk tersebut.

Tabel 1. Margin Pola 1 Pemasaran Ayam Buras di Kabupaten Banyuwangi

\begin{tabular}{|c|c|c|}
\hline Lembaga Pemasaran & Variabel & Pola 1 (Rp/Ekor) \\
\hline \multirow{6}{*}{ Peternak } & Biaya Produksi & Rp 305.884,62 \\
\hline & Biaya Pemasaran & 0,00 \\
\hline & Harga Jual & Rp $30.437,50$ \\
\hline & Biaya pakan & Rp $15.832,57$ \\
\hline & Margin & Rp $14.604,93$ \\
\hline & Keuntungan & Rp $14.604,93$ \\
\hline \multirow{3}{*}{ Konsumen } & Harga Beli & Rp $30.437,50$ \\
\hline & Total Biaya Pemasaran & 0,00 \\
\hline & Margin & Rp $14.604,93$ \\
\hline
\end{tabular}

Tabel 2. Margin Pola 2 Pemasaran Ayam Buras di Kabupaten Banyuwangi

\begin{tabular}{llc}
\hline \multicolumn{1}{c}{ Lembaga Pemasaran } & \multicolumn{1}{c}{ Variabel } & Pola 2 (Rp/Ekor) \\
\hline Peternak & Harga Jual & $\operatorname{Rp~29.300,00}$ \\
\hline \multirow{5}{*}{ Pengepul } & Biaya Produksi & $\operatorname{Rp~32.706,63}$ \\
& Harga Beli & $\operatorname{Rp~29.300,00}$ \\
& Harga Jual & $\operatorname{Rp~38.600,00}$ \\
& Margin & $\operatorname{Rp~9.400,00}$ \\
& Biaya Pemasaran & $\operatorname{Rp~3.506,63}$ \\
\multirow{2}{*}{ Konsumen } & Keuntungan & $\operatorname{Rp~5.893,37}$ \\
\hline & Harga Beli & $\operatorname{Rp~38.600,00}$ \\
& Total Biaya Pemasaran & $\operatorname{Rp~3.506,63}$ \\
\hline
\end{tabular}

\section{Margin Pemasaran}

Margin pemasaran adalah perbedaan harga yang ditawarkan produsen dengan harga yang dibayar konsumen akhir (Simmamora, 2008). Komponen biaya dan margin pemasaran pada pola 1 dapat dilihat pada Tabel 1. Total margin sebesar Rp14.604,93/ekor dan biaya pemasaran Rp0,00/ekor. Komponen biaya dan margin pemasaran pada pola 2 dapat dilihat pada Tabel 2. Total margin sebesar Rp9.400,00/ekor dan total biaya pemasaran Rp3.506,63/ekor.
Komponen biaya dan margin pemasaran pada pola 3 dapat dilihat pada Tabel 3 . Total margin sebesar Rp18.500,00/ekor dan total biaya pemasaran sebesar Rp3.788,00. Komponen biaya dan margin pemasaran pada pola 4 dapat dilihat pada Tabel 4. Total margin sebesar Rp51.000,00/ekor dan total biaya pemasaran sebesar Rp3.706,48.

Total margin terbesar pada semua saluran pemasaran ayam buras di Kabupaten Banyuwangi yaitu terdapat pada pola 4 karena lembaga yang ikut dalam pemasaran ayam buras juga terbanyak dari semua 
saluran pemasaran. Hal ini di dukung pendapat Jumiati (2013), yang mengatakan bahwa semakin panjang dan semakin banyak lembaga pemasaran yang terlibat, maka total biaya pemasaran semakin tinggi dan total margin pemasaran juga semakin besar. Indriyo (2001) menyatakan bahwa semakin panjang dan semakin banyak lembaga pemasaran yang terlibat dalam proses pemasaran akan semakin besar total margin dan laba bersih yang didapat oleh pelaku pemasaran, sebaliknya semakin pendek dan sedikit lembaga pemasaran yang terlibat dalam proses pemasaran semakin kecil total margin dan laba bersih yang didapat lembaga pemasaran. Sejalan dengan pendapat Hutasoit et al. (2017) bahwa lembaga pemasaran dengan marjin paling rendah adalah pengepul.

Tabel 3. Margin Pola 3 Pemasaran Ayam Buras di Kabupaten Banyuwangi

\begin{tabular}{llc}
\hline \multicolumn{1}{c}{ Lembaga Pemasaran } & \multicolumn{1}{c}{ Variabel } & Pola 3 (Rp/Ekor) \\
\hline Peternak & Harga Jual & $\mathrm{Rp} \mathrm{30.000,00}$ \\
\hline \multirow{4}{*}{ Pengepul } & Biaya Produksi & $\mathrm{Rp} \mathrm{30.852,22}$ \\
& Harga Beli & $\mathrm{Rp} \mathrm{30.000,00}$ \\
& Harga Jual & $\mathrm{Rp} \mathrm{37.500,00}$ \\
& Margin & $\mathrm{Rp} 7.500,00$ \\
& Biaya Pemasaran & $\mathrm{Rp} 852,22$ \\
& Keuntungan & $\mathrm{Rp} 6.647,78$ \\
\hline \multirow{3}{*}{ Pedagang Besar } & Biaya Produksi & $\mathrm{Rp} \mathrm{39.333,33}$ \\
& Harga Beli & $\mathrm{Rp} \mathrm{37.500,00}$ \\
& Harga Jual & $\mathrm{Rp} \mathrm{48.500,00}$ \\
& Margin & $\mathrm{Rp} \mathrm{11.000,00}$ \\
\multirow{2}{*}{ Konsumen } & Biaya Pemasaran & $\mathrm{Rp} 1.833,33$ \\
& Keuntungan & $\mathrm{Rp} \mathrm{9.166,67}$ \\
\hline
\end{tabular}

\section{Keuntungan}

Keuntungan pemasaran ayam buras di Kabupaten Banyuwangi dapat dilihat pada Tabel 5. Saluran pemasaran pola 1 tidak menggunakan lembaga pemasaran atau pemasaran secara langsung, peternak memperoleh keuntungan sebesar Rp14.604,93/ekor. Pola 2 menggunakan satu lembaga pemasaran yaitu pengepul. Jumlah keuntungan yang diperoleh pengepul sebesar Rp5.893,37/ekor. Pola 3 menggunakan dua lembaga pemasaran yaitu pengepul dan pedagang besar. Jumlah keuntungan sebesar Rp15.814,45/ekor terdiri dari keuntungan pengepul sebesar Rp6.647,78/ekor dan keuntungan pedagang besar sebesar Rp9.166,67/ekor. Pola 4 menggunakan empat lembaga pemasaran yaitu pengepul, pedagang besar, RPA, dan pedagang pengecer. Jumlah keuntungan sebesar Rp47.293,25/ekor terdiri dari keuntungan pengepul sebesar Rp8.211,11/ekor, keuntungan pedagang besar sebesar Rp9.211,11/ekor, keuntungan RPA sebesar Rp15.433,33/ekor, dan keuntungan pedagang pengecer sebesar Rp14.437,96/ekor.

Keuntungan terbesar diperoleh oleh RPA pada pola 4, biaya pemasaran yang dikeluarkan paling besar diantara lembaga pemasaran ayam buras yang lain dan keuntungan terkecil diperoleh oleh pengepul pola 2. Hasil penelitian menunjukkan bahwa keuntungan terkecil terdapat di pengepul pada pola 2. Hal ini berbeda dari penelitian Mandak (2017) yang menunjukkan bahwa keuntungan terkecil didapat oleh peternak. Menurut Daniel (2002) bahwa untuk mencapai keuntungan yang besar, maka lembaga pemasaran dapat melakukan langkah-langkah seperti menentukan harga jual sesuai dengan keuntungan yang dikehendakinya.

\section{Tingkat Efisiensi Pemasaran}

Tingkat efisiensi pemasaran ayam buras di Kabupaten Banyuwangi disajikan pada Tabel 6. Pola 1 tingkat efisiensi pemasasaran sebesar 0\% dikatakan efisien karena peternak 
tidak mengeluarkan biaya pemasaran untuk memasarkan hasil atau produknya karena konsumen langsung datang kepada peternak. Pola 2 tingkat efisiensi pemasaran sebesar 9,81\% merupakan jumlah efisiensi pemasaran terbesar namun masih masuk dalam kategori efisien. Pola 3 tingkat efisiensi pemasaran sebesar 6,05\% masih masuk kategori efisien. Pola 4 tingkat efisiensi pemasaran sebesar 6,11\%, meskipun melibatkan banyak lembaga dari semua saluran pemasaran ayam buras, pola 4 masih masuk kategori efisien.

Tabel 4. Margin Pola 4 Pemasaran Ayam Buras di Kabupaten Banyuwangi

\begin{tabular}{|c|c|c|}
\hline Lembaga Pemasaran & Variabel & Pola 4 (Rp/Ekor) \\
\hline Peternak & Harga Jual & Rp 28.714,29 \\
\hline \multirow{6}{*}{ Pengepul } & Biaya Produksi & Rp 29.561,90 \\
\hline & Harga Beli & $\operatorname{Rp} 28.714,29$ \\
\hline & Harga Jual & $\operatorname{Rp} 37.500,00$ \\
\hline & Margin & $\operatorname{Rp} 8.500,00$ \\
\hline & Biaya Pemasaran & 288,89 \\
\hline & Keuntungan & $\mathrm{Rp} \quad 8.211,11$ \\
\hline \multirow{6}{*}{ Pedagang Besar } & Biaya Produksi & Rp $37.788,89$ \\
\hline & Harga Beli & Rp $37.500,00$ \\
\hline & Harga Jual & $\operatorname{Rp} 47.000,00$ \\
\hline & Margin & Rp $9.500,00$ \\
\hline & Biaya Pemasaran & 288,89 \\
\hline & Keuntungan & $\mathrm{Rp} \quad 9.211,11$ \\
\hline \multirow{6}{*}{ RPA } & Biaya Produksi & Rp 49.900,00 \\
\hline & Harga Beli & $\mathrm{Rp} 47.000,00$ \\
\hline & Harga Jual & Rp 65.333,33 \\
\hline & Margin & Rp 18.333,33 \\
\hline & Biaya Pemasaran & Rp $2.900,00$ \\
\hline & Keuntungan & Rp $15.433,33$ \\
\hline \multirow{6}{*}{ Pedagang Pengecer } & Biaya Produksi & Rp 65.562,04 \\
\hline & Harga Beli & Rp 65.333,33 \\
\hline & Harga Jual & $\mathrm{Rp} 80.000 .00$ \\
\hline & Margin & Rp $14.666,67$ \\
\hline & Biaya Pemasaran & 228,70 \\
\hline & Keuntungan & Rp $14.437,96$ \\
\hline \multirow{3}{*}{ Konsumen } & Harga Beli & Rp 80.000,00 \\
\hline & Total Biaya Pemasaran & $\mathrm{Rp} \quad 3.706,48$ \\
\hline & Margin & Rp $51.000,00$ \\
\hline
\end{tabular}

Tabel 5. Keuntungan Lembaga Pemasaran Ayam buras di Kabupaten Banyuwangi

\begin{tabular}{lcccc}
\hline \multirow{2}{*}{ Lembaga Pemasaran } & \multicolumn{4}{c}{ Keuntungan (Rp/Ekor) } \\
\cline { 2 - 5 } & Pola 1 & Pola 2 & Pola 3 & Pola 4 \\
\hline Peternak & Rp 14.604,93 & - & - & - \\
Pengepul & - & Rp 5.893,37 & Rp 6.647,78 & Rp 8.211,11 \\
Pedagang Besar & - & - & Rp 9.166,67 & Rp 9.211,11 \\
RPA & - & - & - & Rp 15.433,33 \\
Pedagang Pengecer & - & - & - & $\operatorname{Rp~14.437,96~}$ \\
\hline \multicolumn{1}{c}{ Jumlah } & Rp 14.604,93 & Rp 5.893,37 & Rp 15.814,45 & Rp 47.293,25 \\
\hline
\end{tabular}

Efisiensi pemasaran terbesar pada pola 4 terjadi pada lembaga RPA karena biaya pemasaran yang dikeluarkan lebih banyak dari pada biaya pemasaran yang dikeluarkan oleh lembaga yang lain pada pola 4. Hasil ini sesuai dengan penelitian yang dilakukan oleh Mandak (2017) semua saluran yang diteliti mendapatkan persentase efisiensi karena tingkat efisiensi pemasaran kurang dari 33\%. Hal ini di dukung oleh Rosmawati (2011) 
bahwa jika nilai efisiensi pemasaran 0 sampai $33 \%$ dikategorikan efisien, jika nilai efisiensi pemasaran 34 sampai $67 \%$ dikategorikan kurang efisien dan jika nilai efisiensi pemasaran 68 sampai $100 \%$ dikategorikan tidak efisien.

Tabel 6. Efisiensi Pemasaran Ayam buras di Kabupaten Banyuwangi

\begin{tabular}{lccccc}
\hline \multirow{2}{*}{ Lembaga Pemasaran } & \multicolumn{5}{c}{ Efisiensi Pemasaran (\%) } \\
\cline { 2 - 6 } & Pola 1 & Pola 2 & Pola 3 & Pola 4 & Keterangan \\
\hline Peternak & $0 \%$ & - & - & - & Efisien \\
Pengepul & - & $9,08 \%$ & $2,27 \%$ & $0,77 \%$ & Efisien \\
Pedagang Besar & - & - & $3,78 \%$ & $0,61 \%$ & Efisien \\
RPA & - & - & - & $4,44 \%$ & Efisien \\
Pedagang Pengecer & - & - & - & $0,29 \%$ & Efisien \\
\hline \multicolumn{1}{c}{ Jumlah } & $0 \%$ & $9,08 \%$ & $6,05 \%$ & $6,11 \%$ & \\
\hline
\end{tabular}

\section{KESIMPULAN}

Kesimpulan yang didapatkan dari hasil penelitian ini adalah terdapat 4 pola saluran pemasaran ayam buras yang ada di Kabupaten Banyuwangi. Total margin pemasaran paling besar terdapat pada pola 4 dan yang paling kecil pada pola 1. Jumlah keuntungan terbesar pada pemasaran ayam buras di Kabupaten Banyuwangi yaitu di RPA pada pola 4 dan keuntungan terkecil di pengepul pada pola 2 . Tingkat efisiensi pemasaran ayam buras di Kabupaten Banyuwangi berdasarkan biaya pemasaran dan margin pemasaran dinyatakan efisien pada seluruh pola saluran pemasaran.

\section{DAFTAR PUSTAKA}

Amalia, J.A., H.D. Utami, dan B.A. Nugroho. 2013. Analisis pemasaran usaha ayam broiler skala kecil dan besar pada pola Kemitraan PT Sinar Sarana sentosa Malang. Jurnal Agrisistem. 9(31):36-38.

Arikunto dan suharsimi. 2010. Prosedur penelitian (suatu pendekatan praktik). Rineka Cipta. Jakarta.

BPS (Badan Pusat Statistik) Kabupaten Banyuwangi. 2015. Populasi Ternak Banyuwangi.

https://banyuwangikab.bps.go.id/static table/2015/02/04/104/populasiternak-2008---2015.html. Diakses tanggal 25 September 2018.

Indriyo, G. S. 2001. Akuntansi Biaya Edisi Ketujuh. Penerbit BPFE. Yogyakarta.

Jumiati, E., D.H. Darwanto, dan S. Hartono, 2013. Analisis saluran pemasaran dan marjin pemasaran kelapa dalam di daerah perbatasan Kalimantan Timur. Jurnal Agrifor. 12(1):1-10.
Limbong, W.H. dan P. Sitorus. 1987. Pengantar Tataniaga Pertanian. Jurusan Ilmu-Ilmu Sosial Pertanian. Fakultas Pertanian. Insitut Pertanian Bogor. Bogor.

Mandak, Y., Rorimpandey, B.P.O.V. Waleleng, dan F.N.S. Oroh. 2017. Analisis margin pemasaran ayam broiler di pasar tradisional Kota Manado (study kasus di pasar bersehati Calaca dan Pinasungkulan Karombasan). Jurnal Zootek. 3(1):70-79.

Nazaruddin, R., Suryahadi, dan M. Sarma. 2011. Analisis strategi pemasaran peternakan ayam CV Intan Jaya Abadi Sukabumi. Jurnal Manajemen Pengembangan Industri Kecil Menengah. 6(2):64-73.

Rais, F. 2013. Beef Marketing Efficiency In Gorontalo City. Jurnal Fakultas Jurnal Ilmu-Ilmu Pertanian. 1(1):1-10.

Rasyaf, M. 2011. Beternak Ayam Kampung. Penebar Swadaya. Jakarta.

Rosmawati, H. 2011. Analisis efisiensi pemasaran pisang produksi petani di Kecamatan Lengkiti Kabupaten Ogan Komering Ulu. Jurnal Argonobis. 3(5): 19.

Simmamora.2000. Manajemen Pemasaran Internasional. Jilid II. Salemba Empat. Jakarta.

Sugiyono. 2011. Metode Penelitian Kuantitatif, Kualitatif, dan R\&D. Alfabeta. Bandung.

Hutasoit, G.P.E., Taslim, dan M. Paturochman. 2017. Analisis pola saluran dan marjin pemasaran ayam buras (studi kasus pada peternakan ayam buras Jimmy's Farm, Cipanas Kabupaten Cianjur, Jawa Barat). Students e-Journal. 6(2):1-11. 